\title{
Till Death Do Us Part
}

\author{
David S. Pisetsky, MD, PhD \\ Creative Medical Writing
}

$\mathbf{F}$

rom the moment I saw Ruby Roth, I knew she was

going to die. Ruby was propped upright in an ER bed with an oxygen mask over her face. Ruby was a small woman and looked fragile. Her skin was lax and her hair was matted with sweat.

"Mrs. Roth. I'm Dr. Snider. What's wrong?" I asked.

Ruby looked at me fearfully but said nothing.

"Does it hurt anywhere?" She didn't answer but the drunk in the next bed bellowed, "My head, man, my head."

"Does your chest hurt?" I asked Ruby, ignoring the drunk. Ruby was silent.

I decided that questioning Ruby would be futile and went to the waiting room to find her family. It was $4 \mathrm{AM}$ but the room was steamy and crowded. In the corner, I saw an elderly man staring blankly, his eyes weary behind the thick lenses of his glasses.

"Mr. Roth?" I asked. He nodded yes. "I'm Dr. Snider. I need to ask you some questions about your wife."

Jack was a small, wiry man, with sparse white hair. I could picture Jack and Ruby as one of those elderly couples strolling on Broadway, shrunken but still resilient after a lifetime together.

"How is she?" Jack asked.

"She is in respiratory distress. Tell me what happened tonight."

Jack said Ruby was 79 years old and a little forgetful. At $2 \mathrm{AM}$, he was awakened by her gasping.

"I called an ambulance right away. Will she be OK?" His voice wavered and its pitch rose. "She's all I have."

"We'll do the best we can, Mr. Roth, but your wife is very sick."

I went back to the ER, where a nurse helped me transfer Ruby to a stretcher and put an extra blanket on her. I then took my place at the head of the stretcher and pushed it through a maze of corridors to the ICU.

In the unit, Ruby's condition was a free fall as her lungs filled relentlessly with fluid. When her blood oxygen dipped to 70 and her lips turned dusky blue, I slipped a tube into her lungs.

At noon, I went to see Jack in the waiting room, a forlorn space with just two chairs and a small table.

"How is she?" Jack asked, his voice strained.

"She's holding her own." I said. Even as an intern I had mastered the vague speech of a physician.

I went back to the ICU and worked until 6 PM to stabilize Ruby. Exhausted, I then signed out for the night. I wanted desperately to escape the hospital but I had nothing to look forward to in my apartment. Solitude was not

Address correspondence and reprint requests to Dr. Pisetsky: 151G Durham VA Hospital, Durham, NC 27705. my choice, but my marriage, along with my optimism and good humor, was a casualty of my internship. My wife, Katherine, had moved out 6 weeks before and I still grieved her departure.

Katherine and I had been married 4 years when she left me with a suddenness that was chilling and cruel. We had met as seniors in college, and while I was in medical school, she taught high school to support us. Her dream was to become an editor, and when she landed a job with a publisher in New York, our next stop was dictated.

After my internship began, I hardly saw Katherine. Either I was on call or she was traveling or working late. I would be surprised if we made love more than twice a month, and when we did, I was either distracted or dazed from sleeplessness. I felt my marriage eroding, and for a special evening, I invited Katherine to a restaurant that was touted as the most romantic in the city.

I got to the restaurant at 7 PM and ordered a Perrier. I must have dozed off and was surprised at 7:30 when I was awakened by the waiter. "Will you be ordering?" he asked, sounding disdainful.

Finally, at 8 PM, Katherine arrived. Katherine is a striking woman, with sharp features and dark eyes. She waved to me from the check room and walked lithely across the restaurant.

"Joel, forgive me. I'm late." She tilted her head and smiled in a gesture of apology. "Tell me about your day."

What could I say? That I hadn't slept in 36 hours, that I felt muddled and queasy, that I was worried that two of my patients were dying as we spoke. "Fine," I said. "How was yours?"

Katherine flagged the waiter, ordered a white wine, and then regaled me about a new novelist whose work she was editing. Our waiter returned, and on his suggestion, we ordered rack of venison. As we waited for our food, our conversation drifted. I talked evasively abut my work in the hospital and Katherine would respond with remarks like, "How dreadful." I could not engage her about publishing and soon neither of us spoke.

After a few minutes of painful silence, I smiled tentatively at Katherine but her expression was opaque. She took a sip of wine, and then said without hesitation, "Joel, I've decided to move out."

I was stunned. I could feel my body shudder but I could not make my mouth speak.

Katherine seemed impatient with my silence. "Joel, the marriage is just not working. Since you're an intern, we have no life together."

"Katherine," I said feebly, "I told you internship would be hard, but next year I'm on every fourth night."

"That's not it, Joel."

I felt a dull pain beyond my eyes. "There's another man, isn't there?" I said, sounding desolate. 
Katherine turned her head to look away. "That's not the issue. The problem is between us."

"Who is it, Katherine?"

"Stop it, Joel," she said, making my name a short chopping sound.

"Katherine, how could you do this?" My voice grew shrill.

"Please be quiet. You're making a scene," Katherine said in a loud whisper.

When you spend almost your entire life in a hospital in New York, there is no such thing as scene. "Go to hell, Katherine," I shouted.

"I'm sorry, Joel, I'm leaving," Katherine said, as she glared at me. She strode angrily across the room and left the restaurant without turning back.

As I watched her leave, the waiter brought a plate of deer flesh roasted to a caramel color. I ate without the sensation of food as my mind went numb at the loss of the woman who I thought would light my life forever.

I had not seen Katherine since that night. She picked up her belongings from the apartment on my next weekend on and left a curt note saying she was hiring a lawyer.

Six weeks after that dinner, my life still dislocated and saturated with regret, I ate canned soup and a cheese sandwich in a dreary studio apartment on the upper West Side. I then watched the evening news and fell asleep with my clothes on.

When I awoke the next morning, I was barely refreshed. I got to the hospital early and immediately went to the ICU. Ruby's condition had crashed during the night. Her face and body were completely swollen and the skin around her face looked bruised. I turned up the oxygen and gave her antibiotics and a steroid pulse.

At 9 AM, my beeper went off announcing an admission. On my way to the ER, I stopped to see Jack in the waiting room. "Your wife isn't doing well," I said. "I have added some medicines which should help."

Jack shook his head mournfully and waved me away.

I hurried to the ER for my admission, which was the first of the four on my short-call day. The work was grinding and I quickly grew frazzled. At 4 PM, as I was writing some notes, my pager blasted. Through the static, I heard the words "Call the ICU, STAT."

I sprinted to the unit. Just as I got there, the head nurse yelled, "She's coding!" and put the paddles to Ruby's chest and pushed the buttons on both handles. Ruby's frail body jumped. A yellow line crossed the cardiac monitor like an angry scrawl.

"Shock her again!" I shouted, as the nurse jolted Ruby again and the smell of burning skin rose into the air. This time the monitor showed a regular rhythm.

For the next 20 minutes, I stood by Ruby's bedside, fiddling with five different medicines that flowed into her veins. When I finished the resuscitation, I was elated when I measured Ruby's blood pressure at 120/80 and her pulse at 84 .

I realized I had to check whether Ruby's brain had sur- vived the code. I shined a light into the vacant discs of her eyes and rolled her head back and forth to test the doll's eye reflex. The tests were negative, meaning all that was left of Ruby was a heart that beat and little else that mattered.

I dreaded confronting Jack and procrastinated by writing a detailed note. Finally, I went to the darkened alcove where he was waiting. Before I could speak, Jack took both lapels of my white jacket and shook me hard.

"Stop everything," he sobbed. "Disconnect her from the machine. I can't stand seeing her like that." His small body quivered.

"She'll die if I do that," I said solemnly.

Jack's eyes locked onto mine. "Dr. Snider, if it were your wife, what would you do?" he said and then stared down at the gold wedding ring which I had not yet removed from my finger.

I struggled for what to say, but a thought pressed on my mind and escaped from me. "Was she beautiful?" I asked.

I regretted the remark instantly, but Jack's face registered no distress. "She still is," he said proudly, as his eyes shined with a grace and assurance I longed for in my own life.

"I'll tell the nurses," I said and sighed wearily.

I went to the unit and asked the head nurse to take the tube from Ruby's lungs, unhook the ventilator, and send her to the floor. I then wrote in the chart that Ruby's condition was terminal and that she was a no-code.

At the end of the day, I went to the ward where Ruby had been transferred. She was in the room where the nurses put patients ready to go home or waiting to die.

I knocked on the door and opened it slowly. Jack was sitting in the dim light in a chair next to his wife's bed. The nurses had transformed Ruby into a person again. She wore a clean nightgown and her long white hair had been washed and gathered in a barrette.

Jack touched his finger to his lips to signal me to be quiet. I felt I had intruded so left the room and went home for the night.

When I got to the ward the next day, Ruby's room was empty. A nurse told me that Ruby had died at midnight with Jack at her side, telling her he loved her and kissing her as the beat of her heart finally ceased.

"He left this for you," the nurse said and handed me a small creased envelope.

I went to the end of the ward to open the envelope. In it were two $\$ 10$ bills and a note on a $3 \times 5$ card, written in unsteady script.

You are a wonderful doctor, Dr. Snider. Thank you for everything. This is a little something in appreciation. Please use it to take your wife to dinner. Jack Roth.

It is 5 years since I took care of Ruby Roth but the $\$ 10$ bills remain in the envelope in the middle drawer of my desk. I want to spend them as Jack Roth intended but I cannot.

Katherine never returned and I still search for my Ruby. 